Thes1s writ ten and accepted by the Graduate School but no degree awarded because other requirements for the degree were not completed. 


\section{A GEOLOGIC SECTION}

ALONG THE NORTH SIDE OF THE MISSOURI RIVER

FROM PROVIDENCE, MISSOURI, TO NORTH JEFFERSON, MISSOURI

by

Horace Langin Grriley, A. B.

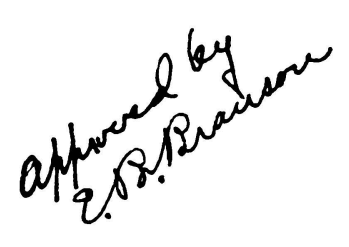

SUBMITTED IN PARTIAL FULFIINENT OF THE

REQUIREMENTS FOR THE DEGREE OF

MASTER OF ARTS

$$
\text { in the }
$$

GRADUATE SCHOOL

of the

UNIVERSITY OF MISSOURI 
$X G 8,78$

CONTENTS

Page

Introduction, with acknowledgments............. 3

Method of Procedure........................... 4

General Geologic Relations.................... 5

Vertical Section........................... 6

Descriptive Geology........................

ordovician.............................

Jefferson City formation..................

St. Peter sandstone.................... 9

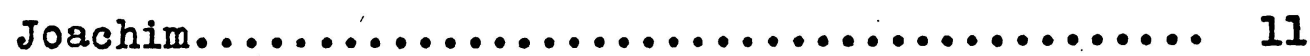

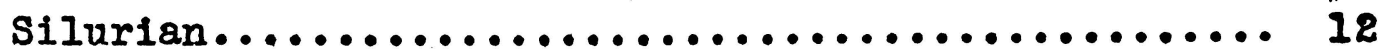

Devonian.............................. 12

Cooper Iimestone........................ 12

Callaway limestone..................... 14

Mississippian.......................... 15

Phelps............................ 15

Chouteau............................. 16

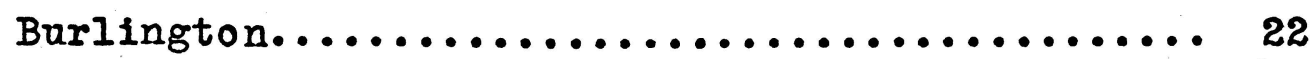

Pennsylvanian........................... 23

Structure............................... 24

Relationships of Formations.................... 26

St. Peter-Jefferson City unconformity........... 26

Joachim-Jefferson City unconformity............ 26

Devonian-ordovician unconformity.............. 28

Callaway-Cooper unconformity................ 28

M1ssissippian-Devonian unconformity............ 28

Phelps-Chouteau and Burlington-Chouteau contacts... 29

Pennsylranian-Mississippian unconformity......... 29

Conclusions................................. 30

Blbliography.............................. 31 


\section{INTRODUCTION}

This thesis covers a careful investigation of the geologic structure observed along the north side of the Missouri River between Providence and North Jefferson. Twelve all-day field trips were made from Columbia to the varlous parts of the section during the spring of 1917, and the data gathered on these trips were used in preparing the structure section and the report on the descriptive geology of the region.

The writer wishes to acknowledge his indebtedness to Dr. E. B. Branson for supervision of the entire work; to Mr. D. K. Greger and Dr. T. A. Tarr for valuable counsel and assistance; and to Mr. A, E. Boughner of Sedalia, Mo., for the loan of the H. K. \& T. Railroad Company's profile of their right-of-way. 


\section{METHOD OF PROCEDURE}

The purpose of the field work was, primarily, to collect sufficient data from measurements made at numerous points along the north side of the Missouri River to draw accurately. in a structure section, the contacts of the various rock formations exposed in the river bluffs. No detailed columnar sections were made but the characteristics and variations of the different formations were carefully noted, to be used in tracing the formations from place to place.

The line chosen for the proposed section is that followed by the M. K. \& T. Railroad from Providence, Mo., approximately twenty-six miles in a southeasterly direction to North Jefferson, Mo. All the geologic units comprising this section could be observed and studied to excellent advantage In the bluffs which form a large part of the northern side of the valley of the Missourt River, and also in the railroad cuts made for the M. K. \& T. track. Horizontal diatances were measured by reference to the telegraph poles and mile posts along the rallroad. Direct vertical measurements with a tape were made where possible on the bluff walls, but for the most part differences in elevation were determined with an anerold barometer, which checked with an error of less than ten feet. All vertical measurements were made with reference to the level of the M. K. \& T. track, a profile of which was obtained from Mr. A. E. Boughner of Sedalia, Mo. 


\section{GENERAL GEOLOGIC RELATIONS}

With reference to the larger geologic features the region through which the section was made lies well down on the northern side of the Ozark structural dome. The strata still dip about eight feet per mile to the northeast. The Ozark dome, which has existed at least approximately in its present form since pre-Cambrian time, largely determined the stratigraphy of the sedimentary rocks of Missouri. Rock formations laid down in Paleozoic seas covered more or less of the sides of the ozark dome, depending upon the extent of the sea advances; some rose on the dome only to a point a little south of the line of this section, and others, comprising part of the Mississippi River embayment, touched only the eastern margin of the uplift.

The table on the following page gives the formations exposed in the section investigated. 
VERTICAL SECTION

period

Formation

Pennsylvanian

(Cherokee

Unc onformity

(Burlington

Mississippian

Chouteau

(Phelps

Unconformity

Deronian

(Callaway

(cooper

Unconformity

Missing

Unconformity

Silurian

(Joachim

Ordovician

?

(st. Peter

Unconformity

$\{$ Jefferson City

Unconformity 


\section{DESCRIPMIVE GEOLOGY}

Ordovician.

JEFFERSON CITY FORMATION - The Jefferson City dolomite, named by Swallow ${ }^{l}$ the second Magnesian limestone, is the lowest and oldest formation exposed along the line of the structure section. It is the top member of the Canadian or Lower Ordovician series in Missouri, and no exposures of the next older formation were found. Van Horn and Buckley in their report on the geology of Monitean county ${ }^{2}$ give the St. Elizabeth formation ${ }^{3}$ as occurring immediately below the Jefferson City dolomite in that area. As the lower contact of the Jefferson City formation is not exposed in the region studied its full thickness could not be measared. At a point about tro and one-half miles west of claysville, where the Boone-Callaway county line and the line of the M. K. \& T. track intersect, 170 feet of Jefferson City rock is exposed. At Providence the Jefferson City dips below the surface. Iithologically the most abundant type of rock in the Jefferson City of this region is a thick-bedded, extremeIy cherty, finely crystalline dolomite which weathers with a roughtly honeycombed surface. Members of the formation

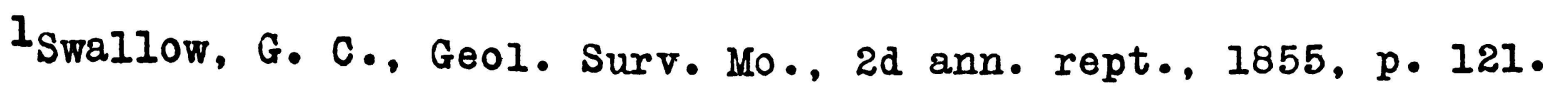
2Report, Mo. Bur. Geol. and Mines, vol. 3, 2d ser., 1905, p. 21. 3 Equivalent to the Roubidoux formation. 
made up of this rock are called the pitted dolomite beds. The chert wich it contains is often oolitic and occurs in irregular beds and also disseminated through the more massive strata.

Alternating with the hard, gray, pitted dolomite beds are zones of so-called "cotton rock," which are somewhat more abundant in the upper part of the formation. The cotton rock beds are almost entirely free from the chert so abundant in the pitted dolomites, and the rock in contrast with the other is also much softer. It is fine-grained, argillaceous, breaks with an irregular colomnar fracture, and has a yellowish white or drab color. Bedding planes are more easily distinguishable than in the pitted dolomite, and the strata vary in thickness from a few inches to about one foot.

Thick beds of a sandy phase of the dolomite occur at various levels throughout the formations. A bed of oolite, in some places several feet thick, occurs in the upper part, and near the top of the first bluff west of North Jefferson a two to three foot bed of gray argillaceous sandstone, similar to the St. Peter sandstone, was found. All the members of the formation except possibly the cotton rock have ripple marks and sun cracks. The presence of thin shale and sandstone beds, ripple marks, sun cracks, oolites, and slight unconformities between many of the beds is strong evidence of shallowwater origin for at least part of the Jefferson City formation. 
Most of the fossils reported have come from two chert beds, one near the bottom and the other near the top of the formation, but fossils are generally rare.

ST. PETER SANDSTONE - This formation is at the bottom of the Champlainian or midale division of the ordovician. It lies unconformably upon the Jefferson City, and in the region investigated it is found only in old erosion channels cut into the top of the underlying formation. The main mass of the st. Peter sandstone which once covered central Missouri was eroded away before the close of ordovician time and only. the protected remnants which lay in depressions in the top of the Jefferson City limestone were left. Farther east, beginning along the line of the C. \& A. Railroad in Callaway County, more extensive deposits of the st. Peter occur, and it thickens to the east.

The formation is a massive, white sandstone composed of well-rounded grains which, except in locally quartzitic phases, are not strongly cemented together. It is so friable, after some weathering, that specimens are broken off with great difficulty and small pieces can be crumbled with ease between the fingers; but as evidenced by outstanding masses on weathered slopes of the Jefferson City formation, the quartzitic phases and some other parts of the rock are more resistant than the dolomite. In appearance it resembles loaf sugar and probably because of this swaliow named it the 5swallow, G. C., Second Ann. Rept., Geol. Surv• Mo., 1855, p. 117. 
"Saccharoidal Sandstone." In general the bedding is indistinct but some crossbedaing is revealed by weathering of the quartzitic type. The isolated masses of St. Peter occurring along the line of the structure section would be broadest on top if completely exposed, taking the shape of the valleys and depressions formed by pre-st. Peter erosion in the Jefferson City limestone. The line representing the St. Peter-Devonian contact has, in many instances, retreated back of the projecting mass of sandstone, and the top of the sandstone outcrop has been rounded off by weathering. In some instances the flat surface produced by erosion which planed off the main body of the formation is still preserved, forming the top of the isolated remnants. The color of the sandstone, which is generally very light gray or white, may be darkened in masses long exposed to weathering. This is especially true in the outer zone and on the rock surface, where various shades of brown and red are produced, principally by iron oxide. The absence of all but isolated outcrops of St. Peter in the region studied makes a complete description of the formation impossible. Crossbedding, ripple marks, and other features indicate shallow water origin. The clean character of the sand and the well-rounded grains indicate wind work. A combination of these conditions making possible a reworking by water of vind-blown sand is probably the best explanation of the origin. 
JOACHIM - The Joachim limestone, formerly called the first Magnesian limestone, ${ }^{6}$ was observed at only one place in the section. It outcrops in the first bluff west of the valley of Little Bonne Femme Creek between Easley and Providence and extends westward along the railroad track for about 500 feet. The Joachim was the next formation formed in the Ordovician sea after the St. Peter sandstone had been deposited, but like the st. Peter in this section it occurs only as an isolated remnant filling an old valley in the top of the Jefferson City limestone. ${ }^{7}$ The contact shows the crests of numerous small folds in Jefferson City beds cut off and massive Joachim limestone above.

In appearance the Joachim is similar to the cotton rook and non-cherty beds of the upper part of the Jefferson City. At the place where it was studied a strong unconformIty with the Jefferson City marked plainly its lower extent. The rock is a massive, dense, dolomitic limestone weathering with a buff surface, but light gray where freshly fractured. The greatest thickness attalned in the region studied is about sixteen feet. Lack of sufficient exposures makes a more complete description impossible.

${ }^{6}$ Swallow, G.C., $2 d$ Ann. Rept., Geol. Surv. Mo., 1855, p. 115. ${ }^{7}$ See discussion of structure features, page 


\section{Silurian}

No formations of Silurian age were found in this section. As all Silurian rocks are absent over most of the area west of the Mississippl River it seems that no part of the Silurian sea ever spread west of what is now the eastern part of Missouri.

\section{Devonian.}

The Deronian of central Missourl is composed of two limestone formations, the Callaway above and the Cooper below, and the two are separated by a marked unconformity.

COOPER LIMESTONE - The Cooper I1mestone is the lowest Devonlan formation ocourring in central Missouri. It comes near the top of the Middle Devonian and was deposited during the maximum extent of the Devonian sea on the northern side of the Ozark uplift. The formation measures about twenty feet In thickness at the places in the section where it was best developed. Unlike the later ordovician formations it is continuous in the region studied, lying on the old erosion surface produced during Upper Ordoviclan, Silurian, and early Deronian time.

The cooper limestoni may be divided into two somewhat distinct parts. The lower of the two is composed of beds of impure, porous, finely-crystalline limestone of a dark gray color, at the bottom of which there is often a basal 
conglomerate of varying thickness. The upper division, in the main of lighter color, is a very dense, marble-like limestone having the appearance of lithographic stone but containing numerous thin irregular lines of calcite running through it. This upper member weathers with a bluish-gray, pitted surface and in places shows stylolitic structure.

The formation is thick bedded except near the top, and is almost completely free from chert. In the lower part one thin, lenticular bed of calcareous sandstone occurs and in the upper member a bed, about tro feet thick, of extremely argillaceous limestone of a buff color was noted. In some outcrops beds of carbonaceous rocks occur near the middle of the formation.

Various layers in the Coover differ in their characteristics. A conglomerate occurs at the base of the formation exposed east of Lupus on the south side of the Missouri River. The source of the fragmental material is clearly the underlying Ordovician rocks, and the great amount of st. Peter sand contained gives the rock a white color. The clastic material is firmly cemented with lime.

A layer of dark gray, porous, siliceous limestone occurs above the conglomerate and merges upward into an argillaceous, arenaceous limestone of a lighter gray color.

At the bottom of the upper part of the formation there is generally five to ten feet of dark graj, very dense limestone breaking with a conchoidal fracture and flaky surface much like rhyolite or other hard, dense, 1gneous rocks. In $1 t$ there are numerous irregular lines of crystalline calcite. 
Above this there occurs fifteen to twenty feet of very dense, marble-like limestone similar to the beds just below except that the rock is of a lighter gray color and contains slightly more calcite.

The top of the formation is made up of one to two feet of dense, ilght-gray limestone with argillaceous matter segregated along wary bedding planes, making it laminar.

The rocks of the Cooper are only locally fossiliferous and the two most abundant fossils are Turbinopsis providensis and a species of Favosites similar to the Favosites alpenensis of the Michigan Devonian.

CALLAWAY IIMESTONE - One good exposure of Callaway limestone is found in the Government quarry at Easley, and another separate mass outerops in the bluffs just west of Little Bonne Femme Creek, and it appears to be absent in the other parts of the section. The callaway fills erosion channels in the top of the cooper, and the greatest thickness attained in this section is about ten feet.

The rock is dark gray, thick-bedded, medium-grained, slightly dolomitic, and contains a small amount of chert. Al1 the beds are fossiliferous, containing various species of spirifers and numerous corals. 
Mississippian.

The Mississippian, or Lower Carboniferous, forms the main part of the river bluffa in the western half of the section, but below Easley it is generally at a considerable height above the railroad. Faulting near the middle of the section raised the block of strata to the east, and erosion has removed the Mississippian beds even on top of the highest hills.

In the region studied the Mississippian series is composed of the Phelps sandstone and Chouteau limestone of Kinderhookian age and the Burlington limestone of the Osagian. The Keokuk, if ever present above the Burlington, was eroded away before Pennsylvanian time.

PHELPS SANDSTONE - This thin but very persistent bed of green sand, because of 1 ts striking characteristics, serves an an excellent marker in the region studied. It lies unconformably upon the Devonian and is taken as the basal formation of the Mississippian series. The sandstone is usually separated from the Chouteau limestone above by a few inches of a soft, impure, sandy shale. Belov it, at a point one mile east of Providence, a valley, about six feet deep, in the Cooper limestone, is filled with thin beds of shale, limestone, and conglomerate. Part of the shale is very carbonaceous and contains imprints of plants. 
East of Providence 3,500 feet another small valley in the top of the cooper is filled with angular blocks of limestone and sand similar to that in the Phelps sandstone which lies in a fifteen-inch bed over the conglomeratic material. At the same place Pholps sandstone extends down into and fills cracks in the top bed of the cooper limestone, again showing the unconformable relationship of the two formations.

One of the best exposures of the Phelps found in the region studied was that at the quarry near Easle $y$, where it lies on top of the Callaway limestone. The formation is al ways thin, rarely "attaining a thickness greater than ten to twelve inches. It varies in texture from a medium to a coarse grained sandstone with the individual grains generally angular and held together with a calcareous cement. More or less angular, water-worn, flint pebbles, varying in size from large sand grains to pieces an inch in diameter, are common in the sand. One of the most striking features of the formation is the presence of fish teeth, which are generally blaok and water worn. The Phelps has a light green color when freshly exposed, but upon weathering the sand becomes reddish-yellow in oolor.

CHOUTEAU LIMESTONE - The Choutean Iimestone was first described and named by Professor G. C. Swallow in $1855 .^{8}$ From a study of fossils collected he correlated it with the chemung ${ }^{8}$ Second ann. rept., Geol. Surv. Mo., 1855, p. 101. 
of New York and considered it as the top member of the Devonlan series in Missour1. After much controversy among many investigators, which extended almost to the present, and the consequent shifting of the Devonian-Mississippian bounary, the Chouteau has come to be considered as of Kinderhookian age. Scott ${ }^{9}$ has given an excellent review of this controversy with the evidence and conclusions advanced by the different participants.

The Chouteau in central and east-central Missouri has been carefully studied and described in theses written by H. M. Scott ${ }^{9}$ and J. P. Connolly $g^{10}$ and in the state survey report on the geology of Moniteau County. ${ }^{11}$ The formation is exposed in the larger river bluffs in the southern part of Boone county, caps the lower hills, and extends several miles up the larger valleys. The thickness, as exposed in this section, ranges from thirty to fifty-five feet. scott, 9 who studied this variation in thickness, explains it by saying that the different beds in the chouteau ohange in thickness from place to place and that the thinning is not dae to a complete disappearance of any individual member.

The upper limit of the Chouteau is not easily determined for there is a thick, intermediate, transition zone before the characteristic crinoidal Burlington beds are reached. In

${ }^{9}$ Scott, H. M., The Chouteau of Central Missouri, thesis, 1914. ${ }^{10}$ Connolly. J. P.. The Chouteau of East-Central Missouri, thesis, 1915.

11Mo. Bureau of Geol, and Mines, vol. 3, sec. series. 
this intermediate zone, about twenty feet thick, few fossils occur and an erosional unconformity has been formed at only one place. This was noted by scott ${ }^{12}$ in his section of the Chouteau at Sweeney in Cooper County. After studying the Chouteau of central missouri with great care, Scott makes the following statement: "In Boone County good exposures of the upper contact fail to reveal any sign of unconformity between the Chouteau and Burlington formations. Indeed, the placing of the upper contact is more or less of an arbitrary matter."

In preparing this section the author used as a line of separation the base of the thick-bedded, non-fossiliferous, arenaceous limestone coming beneath the typical crinoidal Burlington beds, while scott used the top of the arenaceous beds. Shumardellas are persistently very plentiful a few inches below the line used in making the section. A bed representing the time when the seas were shallowest, could it be found, should be used as the division line. Thin lenticular beds of shale occur near the line of separation chosen, and these seem to represent a time when the Mississippian sea was changing and becoming more shallow, perhaps in some places actually moving off the areas it had covered. Soott, ${ }^{13}$ however, in a more detalled study of the chouteau over a wider area reports

\footnotetext{
12 Scott, H. M., master's thesis, p. 12. 13Ibid., p. 18.
} 
the local occurrence near the top of the transition zone of four to twenty inches of very sandy, argillaceous limestone, which weathers with the appearance of shale, and the rock of the whole transition zone is arenaceous and thus represents more turbid water than the typical Burlington beds above or the typical chouteau beds below. The finding of thin, lenticular, arenaceous beds of only local occurrence at various places within the sandy limestone does not afford a means of locating definitely the maximum shallowing of the sea. The author's conclusions in regard to the placing of this contact can be given by again repeating the statement of Scott, who said, "Indeed, the placing of the upper contact is more or less of an arbitrary matter."

If we include the massive, buff, arenaceous beds coming below the crinoidal Burlingt on in the chouteau, the formation may be described in general as composed of two parts, which can be readily differentiated where complete sections are exposed. The upper part of the formation consists of a brownish-gray or buff, magnesian limestone, fil negrained, and argillaceous or sandy. It occurs in beds from ten to trenty feet thick which apparently contain no fossils. In its lower members white masses of quartz are commonly found. The lower division of the formation consists of beds from two inches to two feet in thickness, the majority being quite thin. In many places thin-bedded limestone alternates 
with more massivecherty, magnesian beds. The thin-bedded rock weathers with a light gray color but on freshly-fractured surfaces it is bluish-gray. The upper, more massive beds weather to a buff or tan color. Where the beds of soft and hard limestone alternate in the lower part of the formation a terraced slope is often produced which ends abruptly against the upper massive beds which form a vertical cliff.

The structure of the thinner bedded rock causes a slight amount of weathering to give it a very hackly appearance. This is due to thin, irregular beds of brownish colored limestone alternating with wavy, yellow streaks containing more argillaceous matter.

The following is a detailed section of the Chouteau made by Scott ${ }^{14}$ for the formation as exposed in the Government quarry at Easley:

\section{Rutland section}

11. Typical Burlington limestone. It is coarsely crystalIine and bears brachiopods, corals and crinold stems in abundance. Contact is placed in the middle of

a one foot bed with the advent of the crinoidal fauna. Thickness to top of bluff 30 feet. 10. Heavy bedded, non-fossiliferous, arenaceous limestone. Fresh surface blue, weathered surface yellow. Thickness 21 feet 6 inches. ${ }^{14}$ Scott, H. M., thesis, p. 7 . 
9. Thin, Irregular layers of blue, fine-grained limestone with many calcite seams, alternating with wavy argillaceous layers. Gives a conspicuously streaked appearance on weathering. Persistent horizons of chert nodules at the base and four feet above the base.

Thickness 11 feot 5 inches.

8. Yellowish gray limestone, more coarsely crystalline than the bed above. Numerous blue blotches on the surface, one half to one inch long and about one-sixteenth inch thick. A single bed.

Thickness 4 feet.

7. Limestone in thin irregular beds similar to zone 9. $\Delta$ layer of chert conoretions at the base. Thickness 2 feet 10 inches.

6. Similar to zone 8. Surface has more of a blue cast and is not so blotched in appearance. Composed of two beds of equal thickness, which, on exposure, divide Into beds varying in thiokness from six to fourteen 1nches. Apparently not at all arenaceous. Two horizons of occasional cherty conoretions near the center.

Thlokness 5 feet 10 inches.

5. Similar to zone 9 .

Thlokness 1 foot.

4. Yellowish blue limestone.similar to zone 6. Numerous disseminated calcite crystals. Beds from 3 inches to 2 feet 4 inches in thickness with thin shaly partings. 
No chert nodules except at 8 inches from the top. Thickness 14 feot 4 inches.

3. Blue shale.

Thickness 5 inches.

Total thickness of formation 61 feet 4 inches.

2. Green calcareous sandstone and shale.

Thickness 3 to 4 inches.

1. Devonian limestone to base of quarry.

Thickness about 8 feet.

BURIINGTON FORMATION - In the structure section (Plates I, II, III) Burlington limestone is shown as a comparatively thick formation outcropping in the upper parts of the river bluffs, extending from the westem end of the section at Providence, Mo., to a point about midway between Wilton and Hartsburg, where the strata were elevated 100 feet or more by faulting and subsequently eroded away to a line several miles back from the river. The full thickness of the Burlington strata is not represented along the line of the structure section, but in the higher hills about 175 feet are present.

Ithologically the Burlington, for the most part, is a gray, coarsely orystalline, highly fossiliferous limestone. The beds are generally masgive and on the average range in thickness from one to four feet. The lower beds are thlck, argillaceous and of a buff or brown color; above them crinold remalns become abundant and make up 75 per cent or more of the 
rock material. Chert, in nodules and in various beds parallel to the lines of stratification, is characteristic of the Burlington but is somewhat more abundant in the upper part. Stylolites are present throughout the whole formation.

Caves and sink holes occur, and those existing at the time of the advance of the Pennsylvanian seas were filled with sediments of that period.

Pennsylvanian System.

Only remnants of the lowest member of this system occur in the Missouri River bluffs. These isolated masses of Cherokee shale and sandstone fill erosion depressions which existed in the Burlington limestone at the time of the advance of the Pennsylvanian sea and since the removal of the main body of the formation the remnants have been protected from erosion by the enolosing walls of harder limestone. Pleces of locally quartzitic Pennsylvanian sandstone, and conglomerate masses of various sizes are scattered over the top of the Burlington limestone of this region. Bedded Pennsylvanian shale and sandstone partially fill a valley in Burlington limestone shown on Plate I of the structure section, at a point about midway between Easley and Wilton. 


\section{STRUCTURE}

The structure of the region as shown in the accompanjing section is simple. The general dip of the beds in all the formations is to the northeast and amounts to about eight feet per mile. This northeasterly dip, however, is modified throughout the length of the entire section by folding. The larger folds affect all the formations exposed and are traceable upward from the lowest beds of Jefferson City dolomite to the top of the Burlington. In addition to these larger post-Mississippian folds there are numerous smaller flexures limited to the Jefferson City formation which often give a very wary appearance to its outcrops.

on one side of a valley near the middle of the section Jefferson City dolomite outcrops 175 feet higher than on the other side 800 feet away and this difference is best explained by a fault located somewhere in the valley but not found because the actual Iine of displacement is covered with surface material. In the western half of the section the Jefferson City dolomite never rises more than 100 feet above the railroad used as a datum line, and all the higher hills are capped with the Devonian and Mississippian formations. The fault occurred during post-Mississippian time, and the newly elevated beds in the eastern part of the section were subjected to erosion which planed off the younger formations and exposed the Jefferson City dolomite in the tops of even 
the highest bluffs. As there are no exposures in the valley in which the fault line is placed, conclusive evidence is lacking to support the view that the differential uplift of the beds is caused by a fault rather than by a very sharp fold, but for the reasons given in the following paragraphs it is mapped as a fault.

A strong anticlinal fold mas be plainly seen in the bluff to the west of the valley. In this bluff and also in the side of the valley the Chouteau and Burlington beds are exposed and dip strongly to the east and appear to pass under the floor of the valleg. Outcrops 800 feet away in the east side of the valley show only Jefferson City beds, which dip to the east like those of the Burlington. The Jefferson City rocks occur in the highest part of the hill which adjoins the valley on the east with no younger formations above them, and the younger formations are absent in all that part of the section to the east of this point. In a distance equal to the width of this valley, which is only about 800 feet, the Jefferson City formation shows a differential uplift of more than 175 feet.

Conditions presented by this particular problem, if explainable at all by folding, would make neoeseary an extremeIy sharp and partially overturned fold, and as no folding of this character occurs in this region, a thrust fault instead has been mapped in the accompanying structure section. 
RELATIONSHIPS OF FORMATIONS

The following contacts in this region are unconformities: St. Peter-Jefferson City; Cooper-Joachim; CooperSt. Peter; Cooper-Jefferson Clty; Callaway-Cooper; PhelpsCallaway; Phelps-Cooper; Pennsylvanian-Burlington.

ST. PETER-JEFFERSON CITY UNCONFORMITY - The St. Peter sandstone lies in erosion depressions in the top of the Jefferson City dolomite. Some of the isolated masses of the formation, where they project outward from the slopes of Jefferson City rock, are flat on top, retaining part of the flat surface produced by erosion which remored the main body of the formation. Host of the outcrops of st. Peter are rounded off and their contact with the surrounding Jefferson City beds is covered. This makes it impossible to ascertain the exact character of the depressions which becone filled with the st. Peter sandstone, but remnants of the formation occurring in this section are all extremely narrow in comparison to their vertical measurements. They are generally as extensive vertically as horizontally, and this indicates that the material of which they are composed was deposited in narrow valleys or possibly in sink holes in the Jefferson City formation.

JOACHIL-JEFFERSON CITY UNCONFORMITY - The Joachim limestone, shown in the Providence-Easley part of the section, is the onig rock of that formation which occurs in the region investigated. The main part of this formation was removed by erosion 
during part of the interval between the close of Joachim time and the submergence of the area by the Devonian sea. The marked unconformity which exists between this formation and the overlying Devonian beds precludes any supposition that this isolated mass of the Joachim is all that ever was deposited in the region. The Joachim outcrop is roughly lensshaped with a more or less flat upper surface which is in unconformable contact with Cooper limestone.

The tops of the small folds which occur in the Joachim have been planed off and the cut ends of Joachim beds are now in contact with Cooper limestone, showing the angular unconformith which exists between the two formations. The lateral extent of the Joachim beds is less than one quarter of a mile. At a point about 1,000 feet from the. western end of the outcrop a mass of st. Peter sandstone occurs immediately below the bottom of the Cooper Iimestone. This contact is covered, but measurements show that it is impossible for the Joachim to overlie the st. Peter and continue beneath the surface in that direction.

The Joachim Iimestone outcrops in the bluff immediately to the west of the valley of Iittle Bonne Femme Creek but does not occur east of that stream, and its greatest extent in that direction was to a point located somewhere within the width of the valley.

From the facts just stated it is evident that the Joachim is a broad erosion remnant remaining after the removal of the main part of the formation. 
A structural or erosional valley in the Jefferson. City formation would account for the lower position of the Joachim beds at this place and their protection from erosion which removed the rest of the formation.

DEVONIAN-ORDOVICIAN UNCONFORMITY - The Cooper limestone lies unconformably upon the Joachim and St. Peter rock, but in most of the section it rests upon the Jefferson City beds. It is absent only in the easterm half of the section, where differential uplift subjected it more completely to the action of erosion. A portion of late Ordovician and early Deronian time, as well as all the silurian period, is represented in the unconformity which separates the cooper and the underlying Ordovician formation.

CALLAWAY-COOPER UNCONFORMITY - The Callaway limestone outcrops in the Government quarry at Easley and also at a point about midway between Easley and Providence. At both places the Callaway fills valleys which were formed in the Cooper limestone during the erosion interval which separates the two formations.

MISSISSIPPIAN-DEVONIAN UNCONFORMITY - Phelps sandstone, the lowest member of the Mississippian series, is everywhere in the section coextensive with the Devonian limestones. The unconformable relationship of the rocks of the two periods is shown both by progressive overlap and by deposition in depressions in the top of the limestone. Where the callaway member of the Devonian occurs the Phelps rests unconformably upon. 
Its upper surface, but as the Callaway is generally absent the Phelps-Cooper contact is the one most often found. A valley about ten feet wide in the cooper limestone at a point in the section 600 feet southeast of Providence is filled with angular blocks of limestone and sand similar to the sand in the bed of Phelps overlying the conglomeratic material. At this place cracks extending down into the upper part of the Cooper marble for distances of more than twelve inches are filled with Phelps sandstone.

PHELPS-CHOUTEAU AIND BURIINGTON-CHOUTEAU CONTACTS - The Phelps and Chouteau formations are in conformable contact wherever exposed in the region investigated. Shale of varying thickness occurs betiveen the sandstone and the Chouteau, but there is no evidence of any break in deposition. The Burlington-Choutear contact is also a conformable one.

PENNSYLVAN IAN-MISSISSIPPIAN UUCONFORMITY - The onIV PEnnsylvanian rocks which occur in place in the section fill an erosion valley in the top of the Burlington at a point about midway between Easley and Wilton. 
CONCIUSIONS

While the data secured on minor details of structure are incomplete, in some cases, the author believes that the structure section in plates I, II, and III of this thesis gives a complete representation of the attitude of the formations in the river bluffs south of columbia. This stracture section is the author's main contribution, but a discussion of the anconformities existing in the region has not. previously appeared in the literature, and various details in the descriptions of the formations are also new.

The work of securing data for the report on the descriptive geology was made subordinate to the preparation of the structure section, and in the descriptive part the author has attempted to give only those facts which would be observed in correlating outcrops of the formations shown in the section. Descriptions of all the formations are based entirely on the region studied and do not agree in some respeots with published descriptions for other reglons. 


\section{BIBLIOGRAPHY}

The following list includes papers on the lithology, distribution and oorrelation of the various formations whioh occur in the structure section. Only those references are given which refer to central Missouri and are not purely paleontologic in character.

Ball, S. H., and Smith, A. F.

$$
\begin{aligned}
& \text { Geology of Miller County. } \\
& \qquad \text { Missouri Bureau of Geology and Mines } \\
& \text { Report, Sec. Ser., vol. 1, 1903, pp. 50-119. }
\end{aligned}
$$

Berkey, Charles P.

$$
\begin{aligned}
& \text { Paleogeograp hy of St. Peter Time. } \\
& \text { Geological Soclety of America, Bull., } \\
& \text { Vol. 17, 1906, pp. 229-250. }
\end{aligned}
$$

Branson, E. B.

A Four Mile Section Along the Missourl River South of Columbia, Missouri (abstract).

Soience, new ser., vol. 37, March 21, 1913, p. 459 .

The Devonian Fishes of Missouri.

University of Missouri Bulletin, vol. 15, no. 31 (Science Series, vol. 2, no. 4), 1914.

Branson, E. B., and Greger, D. K.

Devonian of Central Missouri (abstract)

Geological Society of America, Bull., vol. 26, no. 1, March 31, 1915, p. 112 . 
Broadhead, G. C.

Geology of Boone County, Missouri, and the Ozark Uplift.

Report, Missouri Geological Survey, vol. XII, 1898, part III.

Geological Fistory of the Missouri Paleozoic.

American Geologist, vol. 14, 1894, pp. $380-388$.

General Geology (of Missouri).

Report, Missouri Geological Survey, 1874 , pp. 18-34.

The Saccharoidal Sandstone (St. Peter).

American Geologist, vol. 34, 1904, pp. 105-110.

Broadhead, G. C., and. Horwood, C. V.

Geology of Howard County.

Report, Missouri Geological Survey, 1874 , pp. 179-221.

Connolly, J.P.

The Chouteau Formation of East Central Missouri. Master's thesis, Graduate School, University of Missouri, 1915.

Gallaher, John A.

Structural and Economic Geology of Missouri.

Missouri Bureau of Geology and Mines, Preliminary Report, 1900, pp. 111-186. 
Greger, Darling K.

The Devonian of Central Missouri.

$$
\begin{aligned}
& \text { American Journal of Science, fourth } \\
& \text { series, volume 27, May, 1909, pp. 374-378. }
\end{aligned}
$$

Hinds, Henry, and Greene, F. C.

The Stratigraphy of the Pennsylvanian Series in Missouri.

Missouri Bureau of Geology and Mines, second series, volume 13, 1915.

Keyes, Charles R.

The Devonian Interval in Missouri.

Geological Society of America, Bulletin, volume 13, 1902, pp. 267-292.

Paleontology of Missour1 (geological formation described).

Report, Missouri Geological Survey, volume 4, pp. $29-88$.

Marbut, C. F.

Geology of Morgan County.

Report, Missouri Bureau of Geology and

Mines, second serles, volume 7, 1907.

Meek, F. B.

Geology of woniteau County.

Second annual report, Missour1 Geological

Survey, 1855, pp. 96-106. 
Sampson, F. A.

Notes on the Sub-Carboniferous Series at Sedalia, Missouri.

New York Academy of Science Transactions, volume $7,1888, \mathrm{pp} \cdot 246-247$.

Scott, H. M.

The Chouteau Formation of Central Missouri.

Master's thesis, Graduate School, University of Missouri, 1914.

Stewart, Alban.

A Geological Section at Providence, Missouri.

Kansas University Quarterly, volume 4, 1896, pp. 161-162.

Swallow, G. C.

Geology of Missour1.

First and Second Annual Reports, Missouri

Geological Survey, 1855, pp. 186-198.

Van Horn, F. B., and Buckley, E. R.

Geology of Moniteau County.

Missouri Bureau of Geology and Mines,

Report, second series, volume 3, 1905, pp. 21-75. 
See additional file for unfolded version.
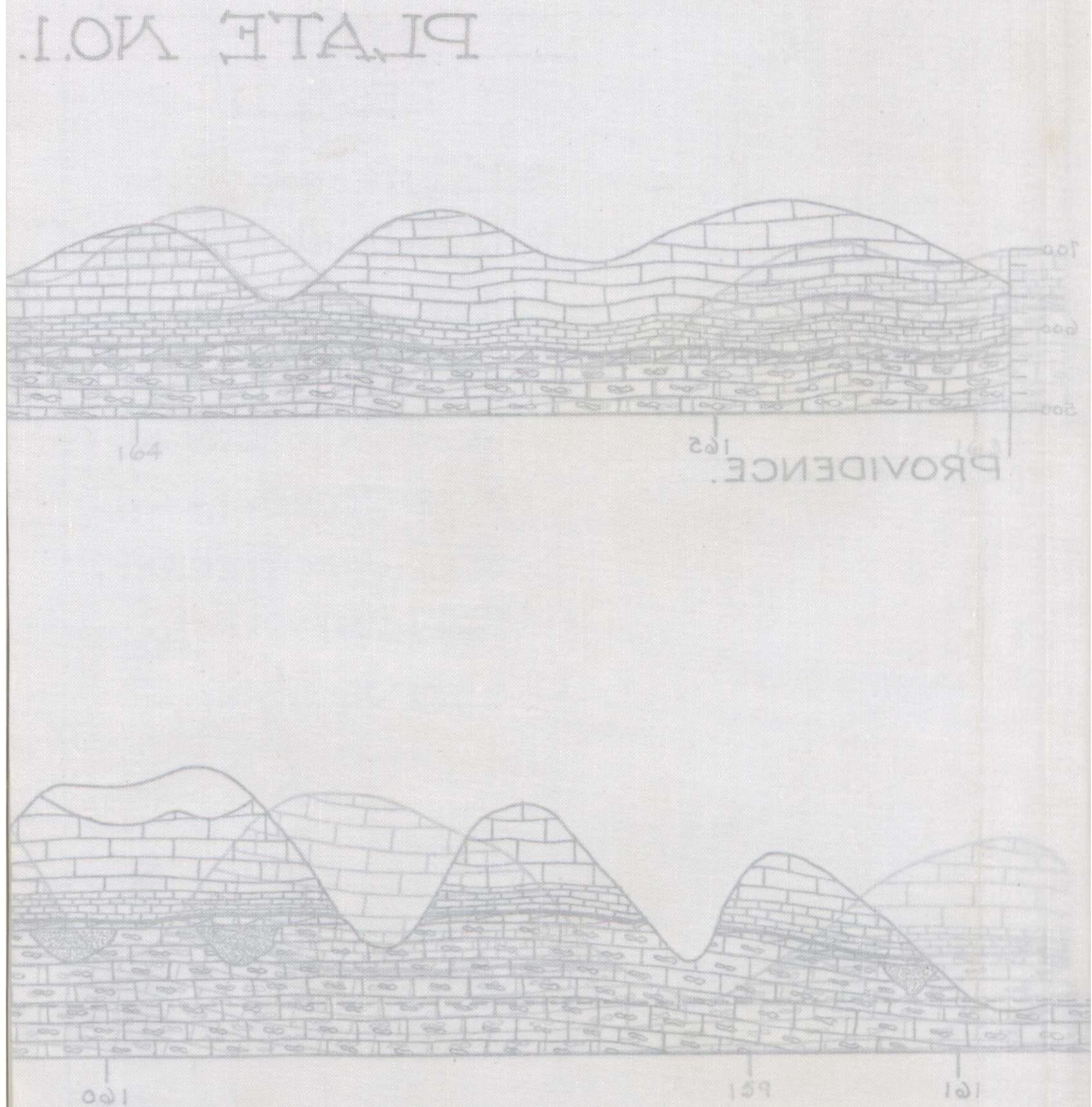

T7OOS = . $11-33 A D 2$ JADTTMV

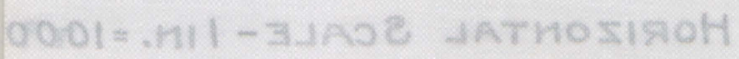


See additional file for unfolded version.
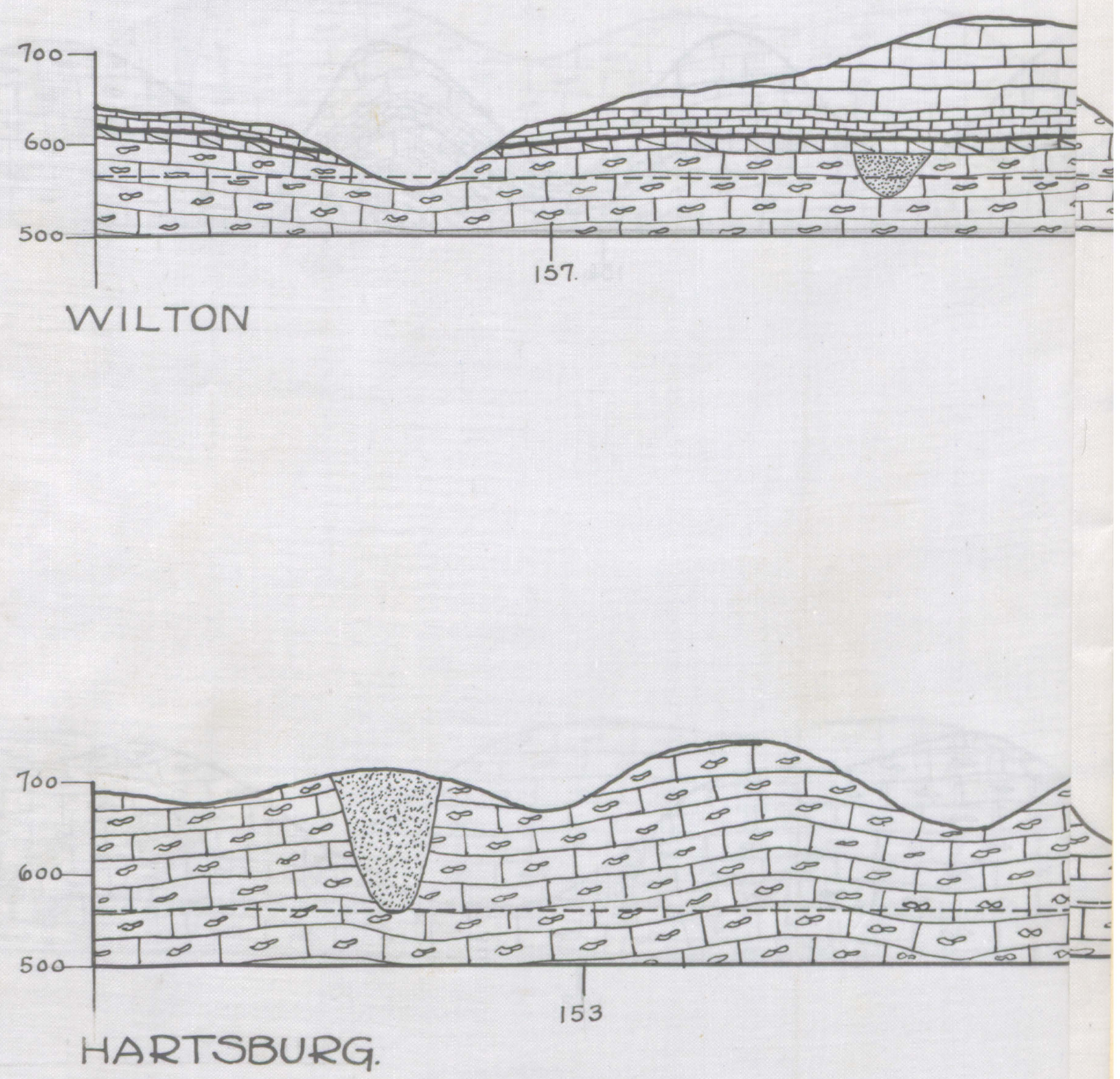
See additional file for unfolded version.

NOO

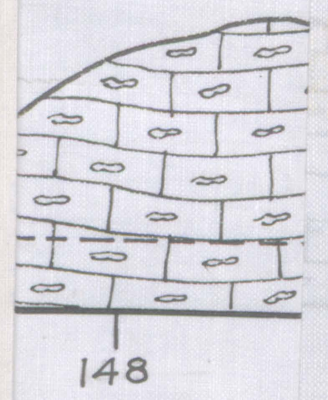

Sㅋ.1P

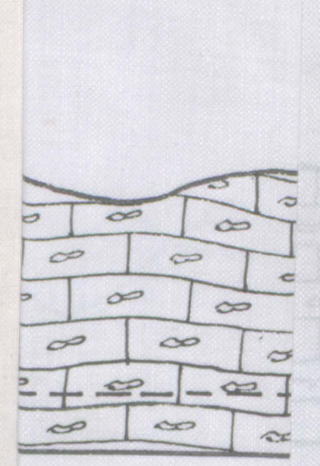

IVTHE)

MAMAVIrenMAC

- MOTDMLISUO

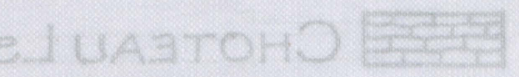

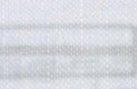

CI YAWA 1 HAO

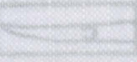

$-15=90002$

- IIN. $=200 \mathrm{~F}$

e. MHOAOU =

ILE $I I N .=I C$ 


\section{UNIVERSITY OF MISSOURI}

Columbia

Professor Talter Miller, Dean of the Graduate School, My dear Dean Hiller,-

I have read with interest the accompany thesis of $\mathrm{Mr}$. Horace Iongtro Griley submitted for the degree of Master of Arts.

It seems to me that the investigation represents about the normal quantity of work that a master's thesis should embrace. A definito problem of modest almensions has been completely porked out. The resulting contribution thus constitutes a finished product, and sete a good example to the beginner in research of the methods to be followed and the alms of to be fulfilled.

$\mathrm{HS} / \mathrm{I}$

Respectfully submitted,

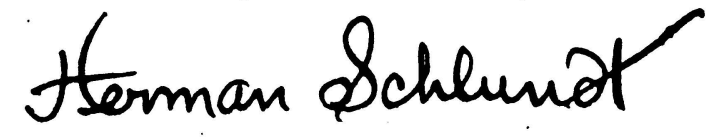




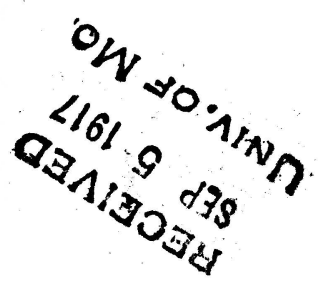

$378.7 \mathrm{M7l}$

$X \in 878$ 
MU Li braries

Griley1917Specsheet. txt

University of Missouri--Col umbia

MU Theses and Dissertations (Pre-1920)

Local identifier

Capture information

Date captured

Scanner manufacturer

Scanner model

Scanning system software

Optical resolution

Color settings

File types

Source information

For mat

Content type

Source I D

Notes
Gril ey 1916

10182016

Zeutschel

OS 15000

Omniscan V.12.8 SR2 (2675)

$600 \mathrm{dpi}$

grayscale, 8 bit and color, 24 bit

Book

Text [with i mages]

$010-100720668$

Pages typed and single-sided.

Title page has signature and perforated

property stamp.

Cal number and date of 9 Nov. 1915 I. S.

written on page 1.

Some pages have handwritten marginalia

and corrections.

Photographs are pasted in.

Derivatives - Access copy

Compression

Editing soft ware

Resolution

Color

File types

Notes

Tiff compressed with LZW before conversion to pdf Adobe Photoshop CS5

$600 \mathrm{dpi}$

Grayscale and color

$p d f$

Grayscale pages cropped, canvassed,

and i mages brightened.

Color pages cropped.

Bl ank pages removed. 